\title{
Review Article \\ Density-Dependent Phase Polyphenism in Nonmodel Locusts: A Minireview
}

\author{
Hojun Song \\ Department of Biology, University of Central Florida, 4000 Central Florida Boulevard, Orlando, FL 32816-2368, USA \\ Correspondence should be addressed to Hojun Song, song@mail.ucf.edu
}

Received 1 June 2010; Accepted 19 September 2010

Academic Editor: Gregory A. Sword

Copyright () 2011 Hojun Song. This is an open access article distributed under the Creative Commons Attribution License, which permits unrestricted use, distribution, and reproduction in any medium, provided the original work is properly cited.

\begin{abstract}
Although the specific mechanisms of locust phase transformation are wellunderstood for model locust species such as the desert locust Schistocerca gregaria and the migratory locust Locusta migratoria, the expressions of density-dependent phase polyphenism in other nonmodel locust species are not wellknown. The present paper is an attempt to review and synthesize what we know about these nonmodel locusts. Based on all available data, I find that locust phase polyphenism is expressed in many different ways in different locust species and identify a pattern that locust species often belong to large taxonomic groups which contain mostly nonswarming grasshopper species. Although locust phase polyphenism has evolved multiple times within Acrididae, I argue that its evolution should be studied from a phylogenetic perspective because I find similar density-dependent phenotypic plasticity among closely related species. Finally, I emphasize the importance of comparative analyses in understanding the evolution of locust phase and propose a phylogeny-based research framework.
\end{abstract}

\section{Introduction}

The contemporary definition of locusts is fairly strict and narrow. Pener [1] defined locusts as grasshoppers that belong to Acrididae (Orthoptera: Caelifera) that meet two criteria: (1) they form at some periods dense groups comprising huge numbers, bands of hoppers, and/or swarms of winged adults which migrate; (2) they are polyphenic in the sense that individuals living separately differ in many characteristics from those living in groups. There are a number of grasshopper species that satisfy the first criterion and thus often loosely called locusts [2-5]. However, the second criterion, the expression of density-dependent phase polyphenism, is rarer [6] and has only been convincingly documented in the migratory locust, Locusta migratoria, the brown locust, Locustana pardalina, the desert locust Schistocerca gregaria, the Central American locust, S. piceifrons, the South American locust, S. cancellata, and the red locust, Nomadacris septemfasciata, and to the lesser degree in the Moroccan locust, Dociostaurus maroccanus. In these species, color, behavior, morphology, biochemistry, and life history traits are strikingly affected by the change in local population density [2]. Those species that cause tremendous agricultural damage but do not express visible phase polyphenism are often referred to as locusts, but whether they strictly fit the definition of "locusts" remains rather ambiguous. Uvarov [5, pages 142-150] dedicated a chapter titled "Antecedents of gregarious behaviour" to discuss these borderline species. Pener and Simpson [2] also listed 23 acridid species that show elements of density-dependent polyphenism and briefly mentioned phase-like expressions in those species not typically categorized as "true locusts."

It is difficult to prove whether a given grasshopper species displays density-dependent phase polyphenism. It is because the presence of density-dependent phase polyphenism is something that has to be tested through explicit experiments [7], especially when its expression is not readily visible. A species in question has to be reared in both isolated and crowded conditions in a carefully controlled manner, and the resulting phenotypes have to be quantified and statistically compared [8]. Also, the expressions of density-dependent polyphenism may be subtle and not manifest in an extreme way found in model locust species such as S. gregaria and L. migratoria. A good example of this can be illustrated in the Australian plague locust, Chortoicetes terminifera, which is convincingly demonstrated to display a strong form 
of density-dependent behavioral polyphenism without the change in color [9]. Just because extreme manifestation of many phase-related characters occurs in model locust species, we cannot expect other locust species to express the same traits. After all, these locust species are the product of their own evolutionary history and finely adapted to their local environments [10]. If we accept the fact that locust phase polyphenism evolved multiple times [4], we also have to accept the fact that there are many ways to become locusts. It is important to realize that many traits associated with locust phase polyphenism do not necessarily evolve as a whole $[4,11]$. Locust phase polyphenism is an ultimate expression of many different phenotypically plastic responses that are affected by the change of local population density. Song and Wenzel [11] showed that the evolution of density-dependent color plasticity precedes the evolution of behavioral plasticity in Cyrtacanthacridinae and that the physiological mechanisms necessary to produce densitydependent color morphs are phylogenetically conserved in the subfamily. Thus, understanding the phylogeny is exceedingly important in understanding the evolution of locust phase polyphenism.

Tremendous advances have been made in understanding the mechanism of phase transformation in S. gregaria and L. migratoria [2], but not much is known about the densitydependent phase polyphenism of nonmodel locust species. The present paper is an attempt to review all available literatures regarding the effect of population density in nonmodel locust species. I do not dwell on $S$. gregaria and $L$. migratoria because these model species have been the subject of several recent reviews [2, 12-14], but I only mention them when comparison and contrast with nonmodel species become relevant. When discussing each species, I try to incorporate available taxonomic and phylogenetic information [15]. Finally, I propose a robust research framework that incorporates a phylogenetic approach in studying the evolution of density-dependent phase polyphenism.

\section{Expression of Density-Dependent Phase Polyphenism of Nonmodel Locusts}

In this section, I review taxonomy, phylogeny, and the existence and expression of density-dependent polyphenism in nonmodel locust species across Acrididae. There is an enormous body of literature dedicated to biology, ecology, population dynamics, and pest management of these species, much of which is reviewed in Uvarov [5, 16], COPR [17], and others. I do not attempt to review these topics again unless they are relevant for discussion. Data presented in the following sections are summarized in Tables 1 and 2.

2.1. Locust Species in Schistocerca. The genus Schistocerca Stål, 1873 contains about fifty species and is widely distributed in the New World. It is difficult to pinpoint the exact number of species in the genus because the most comprehensive revision of the genus by Dirsh [18] made numerous synonymies based on an obscure morphometric species concept, which are now considered to be incorrect.
Harvey [19] revised the Americana complex based on a series of hybridization experiments, and Song [20] revised the Alutacea group based on morphological characters. A large complex of species which is currently synonymized under $S$. nitens needs to be examined thoroughly. Schistocerca is also well known for its transatlantic disjunction distribution in which the desert locust S. gregaria is the only Old World representative of the genus. A considerable amount of controversies and debates have centered on the origin of the desert locust $[21,22]$.

Schistocerca occupies a rather unique position in the study of locusts because it contains multiple locust species. The desert locust S. gregaria is of course the most well known of all locusts in terms of both swarm dynamics and the mechanism of phase transformation [2]. The Central American locust S. piceifrons and the South American locust $S$. cancellata are important swarming locust species in the New World, and the Peru locust S. interrita has recently been recognized as a locust. There have been reports of the American grasshopper S. americana, which is closely related to other swarming species in the genus, being able to form hopper bands and adult swarms [62], but no conclusive evidence exists to show that it is a locust [63]. It is important to realize that the swarming species in Schistocerca do not form a monophyletic group. Based on hybridization studies and phylogenetic studies, it is recognized that swarming $S$. piceifrons is sister to nonswarming S. americana $[19,22,64]$, and swarming $S$. cancellata is sister to nonswarming $S$. pallens $[19,21,22,26]$. In other words, locust phase polyphenism appears to have evolved multiple times even within the same genus. Many nonswarming sedentary Schistocerca species are capable of expressing density-dependent color polyphenism [65-69], suggesting that color plasticity is a phylogenetically conserved trait in the genus [11]. Interestingly, an isolated population of $S$. gregaria in South Africa is not prone to gregarization and is often referred to as the subspecies $S$. gregaria flaviventris [27]. Schimdt and Albütz [70] also found that a population of S. gregaria from Canary Island expressed much reduced phase traits even after intense crowding. Similarly, a Chilean population of $S$. cancellata is also not prone to gregarization [27]. These examples suggest that density-dependent behavioral plasticity is not a fixed trait for these locust species, and it may be reduced or lost due to adaptation to local environments or drift [71].

Schistocerca piceifrons (Walker, 1870) is distributed throughout Central America and the northern part of South America [19, 23, 24]. Two subspecies are recognized, the nominal subspecies and S. piceifrons peruviana which occurs in high elevations of Peru and Ecuador [24, 29, 72]. Recently, a migrant population was found on Socorro Island (Mexico) in the Pacific Ocean [73, 74]. In Mexico, where the locust is commonly referred to as langosta voladora, there are two generations, spring and fall, and the fall generation adults go through a reproductive diapause during the winter dry season [23]. Schistocerca piceifrons is found where there is between 100 and $250 \mathrm{~cm}$ of annual rainfall, distinct dry winter season, and no cold season. It prefers semixerophytic mosaic vegetation and feeds on a wide variety of herbaceous plants. It is a typical swarming 
TABLE 1: Expressions of density-dependent phenotypic plasticity of the species included in this paper. When there is conclusive evidence on presence or absence of density-dependent phenotypic plasticity, it is noted as such. Asterisk denotes the possibility based on inconclusive and anecdotal evidence. Unknown denotes the lack of quantitative data.

\begin{tabular}{|c|c|c|c|c|c|}
\hline \multirow[b]{2}{*}{ Species } & \multicolumn{5}{|c|}{ Density-dependent phenotypic plasticity } \\
\hline & Nymphal color & Morphometrics ratios & Physiology & Behavior & References \\
\hline \multicolumn{6}{|l|}{ Cyrtacanthacridinae } \\
\hline Schistocerca gregaria & present & present & present & present & {$[2,16]$} \\
\hline Schistocerca piceifrons & present & present & present & present* & {$[23-25]$} \\
\hline Schistocerca cancellata & present & present & present & present* & {$[19,26-28]$} \\
\hline Schistocerca interrita & present* & present* & unknown & unknown & [29-32] \\
\hline Nomadacris septemfasciata & present & present & present & present* & {$[16,33-35]$} \\
\hline Patanga succincta & present & present & present & unknown & {$[17,36,37]$} \\
\hline Austracris guttulosa & absent & absent & absent & unknown & {$[17,36-40]$} \\
\hline Anacridium melanorhodon & present & absent & absent & unknown & {$[41,42]$} \\
\hline \multicolumn{6}{|l|}{ Oedipodinae } \\
\hline Locusta migratoria & present & present & present & present & {$[2,16]$} \\
\hline Locustana pardalina & present & present & present & present* & {$[5,16,33,43]$} \\
\hline Oedaleus senegalensis & present* & unknown & unknown & unknown & {$[41]$} \\
\hline Gastrimargus musicus & present & present & unknown & present* & {$[44]$} \\
\hline Pyrgodera armata & present* & unknown & unknown & unknown & {$[45]$} \\
\hline Chortoicetes terminifera & absent & present & present & present & {$[9,46]$} \\
\hline Austroicetes cruciata & absent & present & unknown & unknown & {$[46]$} \\
\hline Aiolopus simulatrix & present* & unknown & present* & unknown & {$[41,47]$} \\
\hline Ceracris kiangsu & unknown & unknown & unknown & unknown & [17] \\
\hline \multicolumn{6}{|l|}{ Calliptaminae } \\
\hline Calliptamus italicus & absent & present & present & present* & {$[48-51]$} \\
\hline \multicolumn{6}{|l|}{ Gomphocerinae } \\
\hline Dociostaurus marrocanus & present & present & present & present* & {$[5,16,52,53]$} \\
\hline Rhammatocerus schistocercoides & present* & present* & unknown & unknown & {$[54,55]$} \\
\hline Gomphocerus sibricus & absent & absent & unknown & unknown & {$[5,56]$} \\
\hline \multicolumn{6}{|l|}{ Melanoplinae } \\
\hline Melanoplus sanguinipes & present & absent & unknown & unknown & {$[5,56-58]$} \\
\hline Melanoplus differentialis & unknown & absent & unknown & unknown & {$[59,60]$} \\
\hline \multicolumn{6}{|l|}{ Proctolabinae } \\
\hline Coscineuta virens & absent & absent & unknown & unknown & {$[61]$} \\
\hline
\end{tabular}

locust with distinct density-dependent phase polyphenism in color, morphology, and other life history traits [24, 25]. In terms of color, nymphs are green at low density, but at high density they develop extensive black pattern in head, pronotum, wingpads, abdomen, and legs with pink or peachred background $[24,25]$.

Schistocerca cancellata (Serville, 1838) is distributed in the southern half of South America, including Argentina, Bolivia, Paraguay, Uruguay, Chile, and southern Brazil [17]. It used to be known as $S$. paranensis, which previously referred to the locust in the New World, but hybridization experiments confirmed that there were two locust species in the New World, the Central American locust S. piceifrons and the South American locust $S$. cancellata $[19,26,64]$. It is adapted to temperate and subtropical climate, and there is an annual cycle of migration and breeding within the invasion area that is strongly influenced by weather and its seasonal variations $[19,27]$. There are several permanent zones of breeding, which consist of an area of desert or semidesert within an annual rainfall of over $500 \mathrm{~mm}$ [17]. The species matures and oviposits in areas where there has been rain. The species used to be a major plague species in the first half of the 20th century [75], but in recent years, large-scale infestations have become infrequent [27], and outbreaks are limited to the semiarid areas in north-west Argentina [76], possibly due to very effective control measures. The South American locust is a classic swarming species with pronounced density-dependent phase polyphenism similar to the congeneric S. gregaria $[19,28]$.

Schistocerca interrita Scudder, 1899, has been known as a nonswarming grasshopper occurring in Peru for a long time [77]. During 1983 and 1984 after the "El Niño" phenomenon, a severe outbreak of $S$. interrita reaching a proportion of a plague was reported in the northern coast of Peru [30]. It has been hypothesized that when there is abundant rainfall due to unusual events such as El Niño, 
TABLE 2: Expressions of swarm dynamics and ecological characteristics of the species included in this paper. When there is conclusive evidence on presence or absence of a given phenomenon, it is noted as such. Asterisk denotes the possibility based on inconclusive and anecdotal evidence. Unknown denotes the lack of quantitative data.

\begin{tabular}{|c|c|c|c|c|c|c|}
\hline \multirow[b]{2}{*}{ Species } & \multicolumn{4}{|c|}{ Swarm dynamics } & \multicolumn{2}{|c|}{ Ecological characters } \\
\hline & $\begin{array}{c}\text { Hopper } \\
\text { band }\end{array}$ & Adult swarm & $\begin{array}{l}\text { Group } \\
\text { mating }\end{array}$ & $\begin{array}{c}\text { Group } \\
\text { oviposition }\end{array}$ & Habitat preference & Food preference \\
\hline \multicolumn{7}{|l|}{ Cyrtacanthacridinae } \\
\hline Schistocerca gregaria & present & present & present & present & arid and semiarid land & herbivorous \\
\hline Schistocerca piceifrons & present & present & present & present & $\begin{array}{l}\text { semixerophytic mosaic } \\
\text { vegetation }\end{array}$ & herbivorous \\
\hline Schistocerca cancellata & present & present & present & present & $\begin{array}{l}\text { desert or semidesert with } \\
\text { annual rainfall of over } \\
500 \mathrm{~mm}\end{array}$ & herbivorous \\
\hline Schistocerca interrita & present & present & present & present & dry wooded area & herbivorous \\
\hline Nomadacris septemfasciata & present & present & absent & absent & $\begin{array}{l}\text { treeless grassland with } \\
\text { seasonal flood }\end{array}$ & graminivorous \\
\hline Patanga succincta & absent & present & absent & absent & grassland & graminivorous \\
\hline Austracris guttulosa & absent & present & absent & absent & grassland & graminivorous \\
\hline Anacridium melanorhodon & present & present & absent & absent & $\begin{array}{l}\text { dry open woodland near } \\
\text { Acacia }\end{array}$ & arborivorous \\
\hline \multicolumn{7}{|l|}{ Oedipodinae } \\
\hline Locusta migratoria & present & present & present & present & variable & graminivorous \\
\hline Locustana pardalina & present & present & present & present & arid land & graminivorous \\
\hline Oedaleus senegalensis & present & present & unknown & unknown & drier savannah & graminivorous \\
\hline Gastrimargus musicus & present & present & present & present & $\begin{array}{l}\text { costal and subcostal regions } \\
\text { of Australia where annual } \\
\text { rainfall is greater than } \\
500 \mathrm{~mm}\end{array}$ & graminivorous \\
\hline Pyrgodera armata & present & absent & unknown & unknown & $\begin{array}{l}\text { alluvial plains and } \\
\text { adjoining hills with clay or } \\
\text { stony soils }\end{array}$ & herbivorous \\
\hline Chortoicetes terminifera & present & present & present & present & semiarid land & graminivorous \\
\hline Austroicetes cruciata & present & present & present & present & $\begin{array}{l}\text { drier and more open } \\
\text { grasslands and semideserts } \\
\text { with } 200-500 \mathrm{~mm} \text { annual } \\
\text { rainfall }\end{array}$ & graminivorous \\
\hline Aiolopus simulatrix & present & present & present* & present* & grassland & graminivorous \\
\hline Ceracris kiangsu & present & absent & unknown & unknown & bamboo forest & $\begin{array}{c}\text { monophagous } \\
\text { on bamboo }\end{array}$ \\
\hline \multicolumn{7}{|l|}{ Calliptaminae } \\
\hline Calliptamus italicus & present & present & present & present & dry steppe zones & herbivorous \\
\hline \multicolumn{7}{|l|}{ Gomphocerinae } \\
\hline Dociostaurus marrocanus & present & present & present & present & $\begin{array}{l}\text { semiarid steppe or semiarid } \\
\text { desert }\end{array}$ & graminivorous \\
\hline Rhammatocerus schistocercoides & present & present & present & present & $\begin{array}{l}\text { shrub-like and wooded } \\
\text { savannas }\end{array}$ & graminivorous \\
\hline Gomphocerus sibricus & present & present & unknown & unknown & forest margins & graminivorous \\
\hline \multicolumn{7}{|l|}{ Melanoplinae } \\
\hline Melanoplus sanguinipes & present* & present & unknown & unknown & grasslands and meadows & $\begin{array}{l}\text { graminivorous/ } \\
\text { forbivorous }\end{array}$ \\
\hline Melanoplus differentialis & present & present & unknown & unknown & $\begin{array}{l}\text { tall herbaceous vegetation } \\
\text { growing in wet meadows }\end{array}$ & $\begin{array}{l}\text { graminivorous/ } \\
\text { forbivorous }\end{array}$ \\
\hline \multicolumn{7}{|l|}{ Proctolabinae } \\
\hline Coscineuta virens & present & present & present & present & forest & $\begin{array}{l}\text { herbivorous/ } \\
\text { forbivorous }\end{array}$ \\
\hline
\end{tabular}


Lambayeque desert becomes a suitable breeding ground for $S$. interrita, which eventually leads to an exponential population growth $[30,31]$. An anecdotal report of a locust swarm in Lambayeque is known from 1578, which can be probably attributed to $S$. interrita [31], but the most recent upsurge occurred in 1997-2003 in Lambayeque and Cajamarca of northern Peru. Schistocerca interrita is adapted to dry wooded area at the elevation of $3500 \mathrm{~m}$ above sea level, and population dynamics and basic ecology have not been thoroughly studied (see $[29,31]$ ). At low density, nymphs are green, but they develop black pattern with yellow background at high density. Unlike the gregarious nymphs of S. piceifrons which develop broad black patterns in the lateral face of the pronotum, the gregarious nymphs of $S$. interrita develop black patterns with clearly defined margins, so that the lateral face of pronotum has a distinct yellow triangle [32]. Both hopper bands and adult swarms are known in this species and sexually mature adults turn yellow.

2.2. Locust Species in the Nomadacris-Patanga-AustracrisValanga Complex. Within Cyrtacanthacridinae, Nomadacris Uvarov, 1923, Patanga Uvarov, 1923, Austracris Uvarov, 1923, and Valanga Uvarov, 1923 form a monophyletic group based on morphological characters including male genitalia, male subgenital plate, and male cerci [11]. The taxonomic history of this group is unnecessarily confusing, which I discuss in detail because I think it is relevant in discussion of the evolution of locust phase polyphenism in this group. Uvarov [78] first described the genus Patanga based on the shape of hind femora, prosternal process, and male subgenital plate. The other three genera were described later in the same publication. Dirsh [79] first suggested that the type species, Gryllus (Locusta) succinctus Johansson, 1763, Uvarov [78] used to describe as Patanga did not correspond to its original description by Johansson. He noted that there was an available name (Acridium assectator Fischer von Waldheim, 1833) matching Uvarov's [78], and Linneaus' original description matched that of Acridium nigricorne Burmeister, 1838, which was a type species of yet another genus Valanga. Uvarov [80] soon published a rebuttal, and Melville [81] carefully summarized this affair. The final opinion from ICZN was published in 1973 in favor of keeping nomenclatural stability [82]. Nevertheless, Dirsh [83] published a revision of Cyrtacanthacris and synonymized Nomadacris, Valanga, Patanga, and Austracris under Cyrtacanthacris on the ground of morphological similarities. Jago [84] criticized Dirsh's action and reinstated the ranking of genera synonymized by Dirsh [83]. In doing so, he suggested that Nomadacris, Patanga, and Austracris were congeneric and lowered the taxonomic ranking to subgenera under Patanga, which had a priority. He also argued that the genus Valanga should be maintained in line with the opinion of the ICZN [82]. Thus, Jago's [84] action resulted in three genera: Cyrtacanthacris, Valanga, and Patanga. Nomadacris septemfasciata was, however, one of the most important locust species, and there were numerous agricultural reports using that name. In order to promote taxonomic stability, Key and Jago [85] proposed to make Nomadacris have a priority over Patanga, on the ground of Jago [84] being the first reviser. Thus, Patanga and Austracris were considered subgenera of Nomadacris. Later, Key and Rentz [86] asserted that the Australian representatives were morphologically distinct and removed Austracris from synonymy.

All this taxonomic confusion is due to the fact that these four genera are very closely related. Because of the conventional usage of the names, I use the generic name sensu Uvarov [78], but it is certainly possible to consider these four genera congeneric. This leads to a very interesting point in terms of the evolution of locust phase polyphenism. Just like Schistocerca, which has a few swarming locust species, but mostly sedentary species, this generic complex also has the mixture of swarming and nonswarming species. Just like $S$. gregaria which is the only African representative of the genus, which happens to express the most extreme form of locust phase polyphenism of all Schistocerca locusts, $N$. septemfasciata is the only African representative of the generic complex, which also happens to express the most extreme form of locust phase polyphenism in the complex. This is a fantastic case of parallel evolution. Locust species in Schistocerca and this generic complex are very similar in terms of their color pattern and the same is true among the sedentary species in these two groups. However, the exact expressions of locust phase polyphenism are distinctly different between the two.

The red locust, Nomadacris septemfasciata (Serville, 1838), is distributed in most of Africa, south of Sahara, and in Madagascar [17]. Seasonal and annual variation of flood gives rise to unstable mosaic of very tall grasses and sedges and short grasses where N. septemfasciata thrives. Several studies were carried out in the Rukwa Valley, Tanganyika (Tanzania), one of three known outbreak areas of the red locust [87-91]. Several studies have emphasized the importance of physical structure of vegetation in concentration of individuals [88-90], and both nymphs and adults are known to roost on stems of Echinochloa pyramidalis, the dominant tall grass and Cyperus longus, the dominant short grass species [90]. The red locust is a classic swarming locust that expresses an extreme form of density-dependent phase polyphenism [5, 33]. Isolated nymphs are green, but crowded nymphs develop extensive black pattern with orange frons and yellow background [41]. Adult morphometrics, number of instars, and the rate of sexual maturation are all affected by the change in population density $[5,34,35]$. Both hopper bands and adult swarms are welldocumented [90, 92], but group mating and group oviposition have not been documented from this species. Adults go through a very long reproductive diapause up to 8 months $[17,87]$, and the particular stage of sexual maturation can be determined by examining the color of hind wing, which changes from transparent to pink to purple red [92].

The Bombay locust, Patanga succincta (Johannson, 1763) is widely distributed in southwestern Asia (India, Philippines, Indonesia, Malaysia, Thailand, Japan, and China) [17, 93]. No major swarm has been reported since 1908 although small populations seem to be consistently found [94]. Adults of $P$. succincta form a typical swarm, but it is not clear from the literature whether this species also exhibits hopper bands. Douthwaite [95] observed nymphal behavior in Thailand. 
Nymphs favored grass species such as Imperata and maize, which co-occurred with low vegetation such as Brachiaria. He observed that nymphs move vertically on maize where they mostly fed. The vertical movement was rapid, but it was not synchronized among other individuals in the population. Feeding occurred during warm weather and nymphs climbed up the maize and descended to Brachiaria which they used as a shelter. Even when the population density is high, the hoppers move little [17]. Isolated nymphs are green, and crowded nymphs develop black mottles with yellowish orange or fawn background, but not extensive black patterns observed in other locust species [36, 37]. Morphometric ratios in adults do seem to be affected [36]. Both group mating and group oviposition are not reported from this species.

The spur-throated locust, Austracris guttulosa (Walker, 1870), is distributed throughout Australia and adjacent regions [96]. It is a tropical, ambivorous species, adapted to monsoon climate with a long dry season [97]. Although it feeds on a wide variety of plants, grass is preferred. Immature adults form a migrating swarm. The size of a typical swarm can be very large and dense, and it can travel up to $400-500 \mathrm{~km}$ in a week [38]. Although adults exhibit impressive migratory swarms, A. guttulosa does not exhibit many traits that are commonly associated with locust phase polyphenism [38]. For example, nymphal color does not become conspicuous upon crowding although densitydependent green/brown polymorphism appears to occur [39], adult morphometric ratios remain constant upon crowding [40], nymphs have never been observed moving in dense bands despite high local densities [38], and oviposition never occurs collectively in egg beds, suggesting the lack of group oviposition [38].

2.3. Anacridium melanorhodon. The genus Anacridium Uvarov, 1923, contains 13 valid species widely distributed in Africa and southern Europe [98]. The identity of $A$. javanicum which was described from a single female specimen from Java is questionable, and it might be a specimen belonging to Valanga which might have been mistaken as Anacridium. The Sahelian tree locust, A. melanorhodon (Walker, 1870), is distributed in the Sahelian zone in Africa. Two subspecies are known, the nominal subspecies occurring in the west and A. melanorhodon arabafrum occurring in the east through Arabia to Iran [17]. It is an arboricolous species, intimately associated with various Acacia species. In the field, especially in winter, swarms occasionally occur. A typical swarm of A. melanorhodon is small, less than one square kilometer, but a swarm as large as $20 \mathrm{~km}$ in length has been observed [42]. One of the characteristics of $A$. melanorhodon is its nocturnal habit. Most feeding and flight activities occur at night, and the species is locally known as sari-el-lel, which means the night wanderer. Both adults and nymphs roost on Acacia trees or other available tall trees. This roosting behavior seems to lead to the concentration of population, which in turn leads to the development of swarms. No characteristic group oviposition as in S. gregaria was observed, but the egg pod density can be high due to the structure of vegetation [42]. Hatchlings from such high-density places gradually concentrate into groups and bands. Cohesive and directional marching behavior has been observed, but the density of hopper bands can be as low as one individual per square meter. Crowded nymphs develop black mottles with yellow background while isolated nymphs are green [41]. Adult morphometric ratios are not affected by population density [42]. The congeneric A. wernerellum is known to behave like a locust in rare circumstances [42], and its response to density is probably similar to $A$. melanorhodon.

2.4. Locust Species in the Oedipodine Tribe Locustini. The oedipodine tribe Locustini is of particular interest because it contains several species prone to density-dependent phenotypic plasticity including the migratory locust, Locusta migratoria, the brown locust, Locustana pardalina, the Senegalese grasshopper, Oedaleus senegalensis, the yellow-winged locust, Gastimargus musicus, and the Iranian grasshopper, Pyrgodera armata. Although there is no phylogenetic work focusing on this tribe as a whole, a recent molecular phylogenetic study by Fries et al. [99] included three genera of this tribe, Locusta, Gastrimargus, and Oedaleus and found that these form a strong monophyletic group. It is unclear how closely the locust species are related within Locustini, but it is intriguing that several major locust species belong to a relatively small tribe, which could suggest that some components of density-dependent phase polyphenism might be phylogenetically conserved in this clade, similar to the cases in Cyrtacanthacridinae.

The monotypic genus Locustana Uvarov, 1921, contains the brown locust, L. pardalina (Walker, 1870), which is one of the major locust species in southern Africa that thrives in the semiarid Karoo region [17]. Because of its agricultural importance, the brown locust has been studied very thoroughly in terms of its life history and swarm dynamics [100]. It is a classic swarming locust, capable of expressing extreme phase characteristics in color, behavior, morphology, and physiology $[5,33,43]$. The phase characteristics of the brown locust were thoroughly investigated early by Faure [33], just soon after the initial formulation of the phase theory [101]. Isolated nymphs are variable in color and exhibit a strong case of homochromy. Green color of the isolated nymphs is associated with high humidity. Crowded nymphs develop characteristic orange and black coloration. Adult morphometric ratios are also strongly affected by crowding. The brown locust displays typical hopper bands and adult swarms, group mating and group oviposition.

The genus Oedaleus Fieber, 1853, currently contains 27 valid species, widely distributed across the Old World, from Africa to Asia and to Australia. Ritchie [102] published the most comprehensive revision to date, in which he discussed the taxonomy and biogeography of the genus in detail. This genus is closely related to another genus of interest, Gastrimargus [102]. Several species in Oedaleus are economically important pests, but the Senegalese grasshopper, O. senegalensis (Krauss, 1877), stands out as the most devastating species [17]. The biology and ecology of this species was recently reviewed by Maiga et al. [103]. This species is widely distributed throughout the tropical and subtropical 
regions, and it is often associated with mesoxerophilic habitats and can be categorized as graminivorous [17]. Marching hopper bands and loose swarms of this species have been frequently reported [104], but no quantitative study on behavioral phase is available. Normal green-brown polymorphism similar to other oedipodines is reported from O. senegalensis [105], but it is not clear if density-dependent color change does occur. Ritchie [105] reported that the nymphs in high-density population show a characteristic brown and black coloration. Launois and Launois-Luong [106] declared that $O$. senegalensis is a true grasshopper because it does not exhibit changes in physiological changes often associated with typical locusts, but gregarious behavior appears to be similar to the locust species. Another member of the genus, O. decorus asiaticus Bei-Bienko, 1941, which occurs widely in Asia, is known to exhibit migratory behavior [107]. Recently, Cease et al. [108] showed that rearing density significantly affected physiological responses in this species but failed to demonstrate a direct correlation among rearing density, color plasticity, and behavioral plasticity.

The genus Gastrimargus Saussure, 1884, currently contains 23 species and 8 subspecies, widely distributed in the tropical grassland of Africa, Asia, and Australasia. Ritchie [109] published the most comprehensive revision to date, in which he discussed the taxonomy and biogeography of the genus in detail and contrasted with the genus Oedaleus which he revised earlier [102]. Gastrimargus favors more humid habitats than Oedaleus although both genera are graminivorous [109]. Of the 23 species, only three species are reported to be of any economical importance, and they are G. africanus, G. marmoratus, and G. musicus [17]. Of these, only the yellow-winged locust, G. musicus (Fabricius, 1775), is known to express density-dependent phase polyphenism [44]. This species is endemic to coastal and subcostral Australia, where rainfall exceeds 20 inches annually. The most thorough and the only study of the biology and ecology of G. musicus was done by Common [44], and no subsequent study was followed despite its pronounced phase expressions. Isolated and crowded locusts differ in terms of color, morphometric ratios, and behavior. This species displays typical hopper bands, adult swarms, group mating, and group oviposition. Based on the specimens collected from an extensive outbreak that occurred in central Queensland between 1939 and 1947, Common [44] tested the existence of locust phase polyphenism in G. musicus and documented that solitarious nymphs have variable color with green/brown polymorphism and gregarious nymphs are medium to dark brown. He also commented that solitarious populations are often patchily distributed in native pastures, and the outbreak in central Queensland was a result of population buildups over several years under favorable environmental conditions.

The monotypic genus Pyrgodera Fischer von Waldheim, 1846, contains the Iranian grasshopper, $P$. armata Fischer von Waldheim, 1846, which is a peculiar grasshopper, easily identified by its high, arched, and laminate pronotal crest, distributed in the Mediterranean regions [45]. It is a minor pest in this region [17] but included in this paper because it is reported to have plastic response to change in population density [45]. Popov [45] encountered an unusual population of $P$. armata in South Iran, which showed a tendency to express different phenotypes at high density. The nymphs of this species are typically green at low density, but he found an aggregation of nymphs that have orange and black patterns, similar to the gregarious nymphs of a typical locust. These colored nymphs in high density formed a small marching band, where other nymphs with conspicuous color would join the band and the green nymphs would remain indifferent to the band. The orange and black pattern continued into the adult instar. Although this species does not develop into a full-blown locust swarm, Popov's observation is indicative of the species expressing densitydependent phenotypic plasticity in terms of both color and nymphal behavior.

2.5. Chortoicetes and Austroicetes. Chortoicetes Brunner von Wattenwyl, 1893, and Austroicetes Uvarov, 1925, are not placed in any tribe within Oedipodinae because they are quite divergent from other members of the subfamily. Fries et al. [99] included both of these genera in their study and found that these two Australian genera form a strong monophyletic group but not related to any other groups within the subfamily. Thus, it is possible to conclude that these two genera are sister to each other but occupy rather an isolated position in Oedipodinae [46].

The Australian plague locust, C. terminifera (Walker, 1870), is the most economically important pest species in Australia [17]. It is found throughout Australia, and its outbreaks are both localized and widespread [96]. Due to its agricultural importance, the life history and population dynamics have been thoroughly studied [110]. The genus Chortoicetes currently contains two species, the nominal species $C$. terminifera and C. sumbaensis which was initially described as Aiolopus sumbaensis by Willemse [111] based on a female specimen collected from the Indonesian island of Sumba. Hollis [112] transferred this species to Chortoicetes based on tegminal venation, but there was no distinct character to warrant a specific status separate from C. terminifera other than size differences and wing patterns. Although it is difficult to confirm, I suspect that it was a migrant individual of C. terminifera that somehow colonized Sumba, which means that the genus should be considered monotypic. Although C. terminifera displays all the behavioral traits typically associated with locusts, including hopper bands, adult swarms, group mating, and group oviposition [96], it does not change color in response to change in population density [46]. Key [46] showed that adult morphometric ratios are affected by crowding, but the degree of transformation is not as pronounced as other typical locusts. Recently, Gray et al. [9] demonstrated that C. terminifera expresses strong behavioral phase polyphenism, and Cullen et al. [113] showed that the behavioral phase transformation is triggered by tactile stimulation of the antennae. These new studies based on quantitative behavioral assay techniques collectively show that density-dependent phase transformation does not necessarily involve change in color.

The genus Austroicetes is probably sister to Chortoicetes and contains 9 valid species. Some members of this genus 
can cause severe damages to crops, but the small plague grasshopper (or sometime small plague locust), A. cruciata (Saussure, 1888), used to be considered the worst grasshopper pest in Western Australia [17]. This species occasionally forms hopper bands and loose adult swarms when population density becomes high. Key [46] demonstrated that this species and the congeneric A. nullarborensis were capable of displaying density-dependent polyphenism in color, adult morphometrics, and behavior.

2.6. Aiolopus simulatrix. The oedipodine genus Aiolopus Fieber, 1853, currently contains 14 species widely distributed throughout the Old World and Australia. Since the revision by Hollis [114], a number of new species have been added to the genus, but this genus still needs to be fully revised. Within Aiolopus, four species (A. simulatrix, $A$. strepens, $A$. longicornis, and $A$. thalassinus) are recognized as economically important species, but the Sudan plague locust, A. simulatrix (Walker, 1870), is the most devastating species of grain and other crops. Joyce [115] described the biology and behavior of $A$. simulatrix (as now synonymized A. savignyi) from East Central Sudan. It forms impressive migratory swarms, but the existence of hopper bands is not well recorded. Nymphs do exhibit density-dependent color plasticity in which nymphs in low density are brown, green, and of a mixture of two colors, whereas crowded nymphs develop a dark pigmentation in pronotum, wingpads, and hind femora [41]. Although there has not been an explicit experiment to study the effect of density in A. simulatrix, Heifetz and Applebaum [47] did such an experiment in a related species $A$. thalassinus. They found that crowding did not result in changes in morphometric ratios or color but affects behavior and other physiological responses such as $\mathrm{CO}_{2}$ release and carbohydrate and lipid levels. Thus, it is possible that $A$. simulatrix may respond similarly to the change in density if it is subjected to a controlled experiment.

2.7. Calliptamus italicus. The genus Calliptamus Serville, 1831, currently contains 15 extant species, and it is widely distributed from northern Africa to Europe and into Russia and China. Of the 15 species, only C. italicus (Linnaeus, 1758 ) is known to swarm, and it is the only known swarming locust in the subfamily Calliptaminae [17]. It forms narrow and long hopper bands (6-2800 $\mathrm{m}$ in length, 3-70 $\mathrm{m}$ in width) [116], and the adults form typical migrating swarms. Unlike the classic locusts, nymphal color is not affected by change in the population density [48], but nymphal behavior does appear to be affected [49] although quantitative behavioral assays have not been applied to this species. This species exhibits physiological responses to the change in density because the locusts reared in a crowded condition mature more rapidly than the ones reared in an isolated setting [5]. Adults also respond morphometrically, and gregarious adults have much longer tegmina than solitarious adults $[50,51]$.

2.8. Dociostaurus marrocanus. The gomphocerine genus Dociostaurus Fieber, 1853, contains three subgenera and 26 species and is widely distributed in the palearctic region. The Moroccan locust, D. marrocanus (Thunberg, 1815), is the only species in the genus known to express an extreme form of density-dependent phase polyphenism in color and morphology in both nymphal and adult stages [5]. Isolated nymphs are yellowish or olive brown with three very distinct black spots on the upper part of hind femora, but crowded nymphs develop orange color in the head and pronotum with faded or no black spots on the hind femora [52]. Gregarious adults are larger in size and have longer tegmina and shorter hind femora than the solitarious ones [53]. It used to be very difficult to rear $D$. marrocanus in a colony setting [117], but recently there has been an advance in this aspect [118]. Characteristic hopper bands and adult swarms are well documented in this species $[5,17,52]$. This species is highly polyphagous and causes significant agricultural damages in the many countries in the Mediterranean zone [119]. However, the Moroccan locust appears to be very selective in terms of its habitat preference; it is often associated with an ecotonal zone between foothills and valleys, at a range of altitudes of 400-800 $\mathrm{m}$ above sea level, with dry-steppe vegetation [117]. The habitat destruction has decreased the severity of outbreak in several developed countries so much, so that the locusts never produce swarms in some cases. Nevertheless, this species is still a major pest species in Afghanistan, Iran, Algeria, Morocco, Uzbekistan, and southern Kazakhstan [117].

2.9. Rhammatocerus schistocercoides. The gomphocerine genus Rhammatocerus Saussure, 1861, currently consists of 18 species, mostly distributed in the Central and South America. The status of many species is uncertain and the genus is in need of a taxonomic revision although several species in this genus are agriculturally important pest species, and the Mato Grosso grasshopper, R. schistocercoides (Rehn, 1906), stands out as the most serious one. It is found in the shrub-like and wooded savannas in South America, and two of the most affected areas include the Brazilian States of Mato Grosso and Rondonia and the Colombian States of Casanare, Meta, and Vichada [54]. The Mato Grosso grasshoppers regularly form very impressive hopper bands [120] and adult swarms [121], but the effect of population density has not been systematically studied. It is unclear if isolated nymphs would behave any differently from crowded ones. Ebratt et al. [55] reared nymphs in isolated and crowded settings and reported that nymphs were green at low density, but red or brown at high density, which also corresponded with the change in morphometric ratios. However, Pierozzi and Lecoq [54] did not find any morphometric differences in the adults collected from high and low densities and suggested that this species should be considered a grasshopper, not a locust, although they recommended that a more thorough investigation on the expression of locust phase needs to be done in this species. This species is highly variable in terms of color, and Lecoq and Pierozzi [122] documented the color change from brown to green upon sexual maturation.

\section{Other Pest Grasshopper Species}

Pener and Simpson [2] list 23 acridid species that show elements of density-dependent polyphenism, which is an 
extended list from Song [4]. In addition to S. gregaria and $L$. migratoria, the species that I discuss in the previous section are the ones that exhibit cohesive migration groups and density-dependent phenotypic plasticity although the degree of expression is quite variable across species. The Rocky Mountain locust, Melanoplus spretus (Walsh, 1866), used to be the most devastating locust species in North America before it abruptly became extinct in the early 20th century [123]. It is likely that M. spretus displayed locust phase polyphenism [124], but most of the data collected for that species predate the formulation of the phase theory [125], and therefore I do not discuss this species in this paper. In this section, I talk about the remaining four species and one species not mentioned by Pener and Simpson [2].

3.1. Melanoplus. The melanopline genus Melanoplus Stål, 1873 , is one of the largest acridid genera containing 243 valid species. No comprehensive revision of this genus is available to date. Many species have very narrow geographic ranges, but some occur throughout North America. Two species that are reported to have density-dependent polyphenism by Pener and Simpson [2] are the migratory grasshopper, $M$. sanguinipes (Fabricius, 1798), and the differential grasshopper, M. differentialis (Thomas, 1865). Both species have been reported to display hopper bands and adult swarms that migrate under a very high-density condition in the first half of the 20th century $[57,59,126]$. Crowding does induce melanization in nymphs [58] in $M$. sanguinipes, but morphometric ratios are not affected. A large body of literature is devoted to the biology and ecology of these two species due to their economical importance [60], but none of the available studies has definitely demonstrated the existence of locust phase polyphenism in these species. Therefore, it would be fair to categorize them as outbreak grasshoppers.

3.2. Gomphocerus sibiricus. The gomphocerine genus Gomphocerus Thunberg, 1815, contains 8 valid species mostly distributed in the Old World, except one Brazilian species G. semicolor, whose taxonomic status is questionable. Among these, the Siberian locust, G. sibiricus (Linnaeus, 1767) (which was sometimes referred to as Aeropus sibiricus before Aeropus was synonymized under Gomphocerus), is one of the most economically important pest species in Russia [5]. This species is restricted mainly to xerophilous forest margins [56] and is prone to outbreak. However, there is no documented report of G. sibiricus responding to population density, suggesting that its common name has been misapplied.

3.3. Ceracris kiangsu. The genus Ceracris Walker, 1870, contains 12 described species which are distributed throughout China. The Orthoptera Species File currently places the genus in the tribe Parapleurini of the subfamily Oedipodinae [127], but Chinese researchers have always placed it under Arcypteridae [128], which is a junior synonym of the tribe Arcypterini of Gomphocerinae. The genus includes a few economically important species, and the yellow-spined bamboo locust, C. kiangsu Tsai, 1929, is known to be the most important agricultural pest of bamboos [129]. Earlier studies described the nymphs and adults to be gregarious $[130,131]$ and also reported the migrating bands of the late instar nymphs [131]. These earlier studies led Song [4] and Pener and Simpson [2] to include C. kiangsu as one of the species exhibiting a certain level of density-dependent phase polyphenism, but in fact, there is no definitive report of this species being able to change color, morphology, or behavior in response to change in population density. Based on published data, it is possible to deduce that $C$. kiangsu specializes in feeding on bamboo, and its life history is intimately associated with the bamboo forest. Recent studies have shown that C. kiangsu is attracted to human urine possibly to supplement sodium and nitrogenous compounds which are lacking in bamboos [132], and some have advocated the use of human urine to bait and control this pest [133]. All available data point to a conclusion that $C$. kiangsu is an outbreak species but does not fit the definition of a locust.

3.4. Coscineuta virens. The genus Coscineuta Stål, 1873, currently contains 8 valid species, and it is the only member of the basal proctolabine tribe Coscineutini [134]. Coscineuta is widely distributed in South America, but the Moruga grasshopper, C. virens (Thunberg, 1815), is currently restricted to the southeastern region in Trinidad. Other specimens of this species are known from Guyana and Uruguay, but there is no report of recent occurrence [61]. The Moruga grasshopper, also locally known as Courtac, has been a principal acridid pest of Trinidad feeding on a wide variety of crops including citrus, coffee, cocoa, mango, cassava, and several vegetables [61]. This species is of particular interest because it is known to be gregarious in all stages of life. Nymphs are characteristically colored black and yellow, reminiscent of typical pyrmorphid nymphs, and form very dense and mobile marching bands. Because of this locust-like behavior, Popov et al. [61] examined the existence of density-dependent phase characteristics in this species but found that this species was not affected by isolation or crowing in any meaningful way. In fact, the species appeared to be always in the "gregarious phase" at least in terms of behavior. No followup study has been done on this interesting species of grasshopper.

\section{Evolution of Density-Dependent Phase Polyphenism in Acrididae}

Locust phase polyphenism has evolved multiple times within Acrididae. The convergent evolution of this phenomenon should not be understated. Only a handful of species are capable of expressing locust phase polyphenism out of more than 6400 valid species of Acrididae. In other words, only about $0.29 \%$ of known acridids (19 legitimate locust species out of 6444 valid acridid species) can be categorized as locusts. The proportion of the locusts that express fullblown phase polyphenism is even smaller. Based on the present paper, it is possible to conclude that locust phase polyphenism has evolved only in four acridid subfamilies, Cyrtacanthacridinae, Oedipodinae, Gomphocerinae, and Calliptaminae, out of 24 currently recognized subfamilies. 
Within each subfamily (except Calliptaminae which only contains one locust species), it has evolved multiple times. Although the ultimate expression of locust phase, densitydependent phenotypic plasticity leading to gregarization and migration, is similar across different locust species, the specific mechanisms behind phase transformation are quite variable. In fact, the deep understanding we have gained through studying $S$. gregaria and L. migratoria is probably not directly applicable to many nonmodel locust species. This perspective is quite different from a traditional view of studying locusts in which researchers used to look for specific physiological phase characteristics such as changes in color and morphometric ratios in the species in question to determine whether it is a "true locust" or not [135]. The more appropriate view in light of the contemporary definition of locusts should be based on the presence of any density-dependent phenotypic plasticity whether the expression is morphology, physiology, or behavior, or any combination of these.

From a taxonomic point of view, an interesting general pattern emerges from the present paper. Typically, locust species often belong to larger taxonomic groups in which most species are not locusts. For example, the Italian locust is the only locust species out of 15 Calliptamus species, and the Moroccan locust is the only locust out of 26 Dociostaurus species. Schistocerca contains only four locust species out of 50 species, all of which are nonswarming sedentary species. This pattern can also be extended to monotypic genera such as Locusta and Locustana, both of which belong to Locustini which contains 72 species, most of which are sedentary grasshoppers. Similarly, the monotypic genus Chortoicetes forms a monophyletic group with Austroicetes which includes nonswarming species. There is no known case of every species of a given taxonomic group being locusts. Every species in a given taxonomic group (whether a genus or a tribe) is closely related phylogenetically and must be very similar to each other morphologically, biologically, and ecologically. But, only a small proportion of a given taxonomic group expresses locust phase polyphenism. What makes some species locusts while other species in the same taxonomic group remain as regular grasshoppers? Do the nonswarming species in these taxonomic groups have the potential to develop locust phase polyphenism?

These are certainly very difficult questions to answer, and the obvious answer would be "we do not know." Locusts are exceptionally adapted to their local environments, and these locust species may simply have the best combination of the traits that make them the most successful, compared to other species in the same taxonomic groups, or there may be some species that are capable of becoming locusts, but the environmental conditions are simply not conducive to the expression of locust phase polyphenism, and we cannot know whether one would be a locust or not a priori. For example, the recent outbreak of S. interrita was not anticipated because the species was not known to be a locust, but the El Niño phenomenon created an exceptionally favorable environment for the species to express its hidden potential to express locust phase polyphenism [29].
In addition to the general pattern that only a small proportion of species in a given taxonomic group expresses locust phase polyphenism, there is another interesting pattern which is not readily noticeable unless one understands the phylogeny of these locusts. Although locust phase polyphenism has evolved convergently, its evolution does not appear to be totally random especially when the phase characteristics of closely related locusts are examined. There are four cases in which there are multiple locust species occurring in supposedly monophyletic groups. They are the locust species in the Schistocerca, Nomadacris-PatangaAustracris-Valanga, Locustini, and Chortoicetes-Austroicetes clades. Phase-related characters are remarkably similar across different locust species within each monophyletic group (Tables 1 and 2). For instance, the locust species within Schistocerca all exhibit a similar form of density-dependent phenotypic plasticity in color, morphology, physiology, and behavior. They all behave very similarly at high population density and prefer dry habitat and herbaceous plants. Although in the same subfamily, the locust species in the Nomadacris-Patanga-Austracris-Valanga clade behave quite differently from Schistocerca. Adult swarms are prominent in this clade, but hopper bands are only weakly or not at all expressed. These species exhibit neither group mating nor group oviposition, and they distinctly prefer grassland habitats and grasses. The locust species in Locustini also favor grasses but have broader habitat preferences. They all express typical swarm dynamics both as nymphs and as adults and show pronounced density-dependent phenotypic plasticity in many traits. The Chortoicetes-Austroicetes clade belongs to the same subfamily as Locustini, thus the locust species in this clade show similar ecological characteristics but do not change color at high density.

Throughout the locust literatures, comparisons among the locust species belonging to different taxonomic groups have seldom been made. The reason for this lack of comparative studies may be due to the fact that several of these locust species are monotypic and thus assumed to be somewhat unique. Although different locust species may not always form a monophyletic group within each clade, it is important to understand that the evolution of locust phase polyphenism is shaped by the shared ancestry and the adaptation to local environmental conditions. For example, Song and Wenzel [11] showed that N. septemfasciata, P. succincta, and A. guttulosa form a monophyletic group based on morphological characters and that the individual components of locust phase polyphenism evolve at different times and its full expression is achieved when these components are expressed together. Because of the shared ancestry, these locust species exhibit the same density-dependent plastic responses, but they also exhibit unique traits and ecological adaptations because they are specifically adapted to their local environments. Another example can be found in Schistocerca. Many sedentary species in the genus Schistocerca display density-dependent color plasticity [65-69], which indicates that the physiological mechanisms behind this plastic reaction norm may be a phylogenetically conserved ancestral trait. Thus, the development of conspicuous nymphal coloration in the gregarious phase of $S$. gregaria is 
not a novel trait in locusts, but an expression of ancestral phenotypic plasticity [4]. These examples are, however, based not on experimental data, but on the fragmentary reports published in various literature sources [11]. Nevertheless, it demonstrated the importance of a phylogenetic perspective in understanding the evolution of locust phase polyphenism.

\section{A Call for a Phylogeny-Based Research Program in the Study of Locust Phase Polyphenism}

For the last century since the formulation of the phase theory, especially for the last two decades, tremendous advances have been made in the study of locust phase polyphenism using S. gregaria and L. migratoria as model systems. Despite the deep understanding we have gained based on a modelbased approach, we know surprisingly little about other nonmodel locust species. In this paper, I show that many of the nonmodel locusts exhibit different forms of locust phase polyphenism and what we know about the model species do not necessarily translate to these nonmodel species. As a parallel illustration, we have accumulated an enormous body of information on the making of a fruit fly, Drosophila melanogaster, a very specialized dipteran species, but this does not mean that we have learned everything about the extremely diverse order of Diptera, nor does it mean what is known about the fruit fly is directly applicable to other flies. The model-based approach in studying locust phase polyphenism is undoubtedly invaluable, but a much richer understanding of this phenomenon can be gained if it is complemented with a phylogenetic approach.

Applying a phylogenetic perspective to the study of speciation, adaptation, behavioral ecology, and character evolution has often resulted in deeper and more comprehensive understandings of the subject [136]. A phylogeny-based research framework in locust phase polyphenism can allow us to investigate relevant questions such as reconstructing ancestral state of individual components of locust phase, tracing the origin and transformation of different phaserelated traits, and testing correlations between different phase-related traits. This approach can predict that nonswarming species might be capable of expressing phase polyphenism when favorable environmental conditions arise and also help form testable hypotheses on the phase expressions of nonmodel locust species that are closely related to the model species. For instance, what we know about $S$. gregaria can form a basis for studying other locust species in Schistocerca because of their phylogenetic relationships. Take the mechanoreceptors present in the outer face of hind femora for an example. The behavioral phase transformation can be achieved by stimulating these mechanoreceptors in S. gregaria [137]. An informed null hypothesis then may be that S. piceifrons or S. cancellata can also respond to density in a similar way. Cullen et al. [113] recently showed that the tactile stimuli are sensed by the antennal receptors in C. terminifera, rather than hind femora. This suggests that what is known about $S$. gregaria might not apply to $C$. terminifera, but what we gain from studying $C$. terminifera can form a basis for studying Austroicetes cruciata because of their phylogenetic relationships. It is thus possible to predict that $A$. cruciata is likely to respond to antennal stimulation rather than leg stimulation. Likewise, what we know about L. migratoria is a good starting point for understanding the locust phase polyphenism in L. pardalina, G. musicus, and O. senegalensis because they all belong to Locustini. By studying both similarities and differences among different locust species in the same monophyletic groups, we can gain greater understanding of the evolution of locust phase polyphenism.

This phylogeny-based research program certainly has several challenges. Reconstructing a robust phylogeny is always a difficult endeavor laden with problems of taxon and character sampling, and numerous assumptions about phylogenetic reconstruction methods. For locust research, the problem is exacerbated because the use of mitochondrial genes, which is commonly employed in inferring the relationships among closely related species, is difficult because Acrididae is known to be severely affected by nuclear mitochondrial pseudogenes [138-140]. Generating data on density-dependent phenotypic plasticity in explicitly controlled laboratory settings for all species in a given monophyletic group is extremely challenging. Even the cost of maintaining colonies of different species would be prohibitively high. Thus, this research program would necessarily have to be a long-term international collaborative project.

Despite all these difficulties, I would still argue that this phylogeny-based approach would considerably expand upon the insights we have gained from the current model-based approach. In this paper, I have identified four candidate monophyletic groups which contain multiple locust species and many nonswarming species. Of these, I argue that the locust research community should initially focus on Schistocerca and Locustini. We can take advantage of what we have learned so far based on the study of S. gregaria and L. migratoria and begin to understand the evolution of locust phase polyphenism in other locust species in these two groups with phylogeny-based, informed predictions. Exciting results from this research program will eventually form a basis for investigating other nonmodel locust species.

\section{Conclusion}

In this study, I have performed a literature review focusing on locust phase polyphenism of nonmodel locust species. The most striking finding is how little we know about these nonmodel locust species. So far, there have been only three locust species (S. gregaria, L. migratoria, and C. terminifera) that have been investigated using modern quantitative behavioral assay techniques $[2,8,9]$. We do not know what specific stimulus triggers phase transformation in other species. Endocrine responses, biochemical changes, and molecular expressions in response to change in density are completely unknown for most of the locust species. This lack of knowledge means that there are many new exciting findings and insights waiting to be discovered. The major 
theme of this paper is that there are many ways to become locusts, and the evolution of locust phase polyphenism has to be understood through the lens of phylogeny. We have learned a great deal about the specific mechanisms of phase transformation of model locust species over the past few decades. Now, it is time to expand the study of locust phase polyphenism to these nonmodel locust species to gain a deeper understanding of this fascinating phenomenon.

\section{Acknowledgments}

The author thanks Alex Latchininsky for allowing him to think about this subject in depth. Greg Sword generously shared his unpublished data. Greg Sword and two anonymous reviewers provided valuable comments on the earlier version of this paper. This work was supported by the National Science Foundation Grant no. DEB-0816962.

\section{References}

[1] M. P. Pener, "Endocrine aspects of phase polymorphism in locusts," in Invertebrate Endocrinology, Endocrinology of Insects, R. G. H. Downer and H. Laufer, Eds., vol. 1, pp. 379394, Alan R. Liss, New York, NY, USA, 1983.

[2] M. P. Pener and S. J. Simpson, "Locust phase polyphenism: an update," Advances in Insect Physiology, vol. 36, pp. 1-272, 2009.

[3] M. P. Pener and Y. Yerushalmi, "The physiology of locust phase polymorphism: an update," Journal of Insect Physiology, vol. 44, no. 5-6, pp. 365-377, 1998.

[4] H. Song, "Phylogenetic perspectives on the evolution of locust phase polyphenism," Journal of Orthoptera Research, vol. 14, no. 2, pp. 235-245, 2005.

[5] B. P. Uvarov, Grasshoppers and Locusts, vol. 2, Centre for Overseas Pest Research, London, UK, 1977.

[6] S. W. Applebaum and Y. Heifetz, "Density-dependent physiological phase in insects," Annual Review of Entomology, vol. 44, pp. 317-341, 1999.

[7] C. D. Schlichting and M. Pigliucci, Phenotypic Evolution: A Reaction Norm Perspective, Sinauer Associates, Sunderland, Mass, USA, 1988.

[8] S. J. Simpson, A. R. McCaffery, and B. F. Hägele, "A behavioural analysis of phase change in the desert locust," Biological Reviews of the Cambridge Philosophical Society, vol. 74, no. 4, pp. 461-480, 1999.

[9] L. J. Gray, G. A. Sword, M. L. Anstey, F. J. Clissold, and S. J. Simpson, "Behavioural phase polyphenism in the Australian plague locust (Chortoicetes terminifera)," Biology Letters, vol. 5, no. 3, pp. 306-309, 2009.

[10] N. D. Jago, "The evolutionary interrelationships of phase attributes and mobility in the Acridoidea," in Proceedings of the 3rd Triennial Meeting Pan American Acridological Society, vol. 3, pp. 65-91, 1985.

[11] H. Song and J. W. Wenzel, "Phylogeny of bird-grasshopper subfamily Cyrtacanthacridinae (Orthoptera: Acrididae) and the evolution of locust phase polyphenism," Cladistics, vol. 24, no. 4, pp. 515-542, 2008.

[12] A. Hassanali, P. G. N. Njagi, and M. O. Bashir, "Chemical ecology of locusts and related acridids," Annual Review of Entomology, vol. 50, pp. 223-245, 2005.

[13] G. A. Sword and S. J. Simpson, "Locusts," Current Biology, vol. 18, no. 9, pp. R364-R366, 2008.
[14] S. Tanaka, "Corazonin and locust phase polyphenism," Applied Entomology and Zoology, vol. 41, no. 2, pp. 179-193, 2006.

[15] D. C. Eades and D. Otte, "Orthoptera Species File Online," 2010, Version 2.0/4.0, http://Orthoptera.SpeciesFile.org.

[16] B. P. Uvarov, Grasshoppers and Locusts, vol. 1, Cambridge University Press, Cambridge, UK, 1966.

[17] COPR, The Locust and Grasshopper Agricultural Manual, Centre for Overseas Pest Research, London, UK, 1982.

[18] V. M. Dirsh, Genus Schistocerca (Acridomorpha, Insecta), Dr. W. Junk B.V. Publishers, The Hague, The Netherlands, 1974.

[19] A. W. Harvey, "A reclassification of the Schistocerca americana complex (Orthoptera: Acrididae)," Acrida, vol. 10, pp. 61-77, 1981.

[20] H. Song, "Revision of the Alutacea group of genus Schistocerca (Orthoptera: Acrididae: Cyrtacanthacridinae)," Annals of the Entomological Society of America, vol. 97, no. 3, pp. 420436, 2004.

[21] N. R. Lovejoy, S. P. Mullen, G. A. Sword, R. F. Chapman, and R. G. Harrison, "Ancient trans-Atlantic flight explains locust biogeography: molecular phylogenetics of Schistocerca," Proceedings of the Royal Society B: Biological Sciences, vol. 273, no. 1588, pp. 767-774, 2006.

[22] H. Song, "On the origin of the desert locust Schistocerca gregaria (Forskål) (Orthoptera: Acrididae: Cyrtacanthacridinae)," Proceedings of the Royal Society B: Biological Sciences, vol. 271, no. 1548, pp. 1641-1648, 2004.

[23] L. Barrientos-Lozano, Ecología, Manejo y Control de la Langosta Voladora (Schistocerca Piceifrons Piceifrons, Walker), Instituto Tecnológico de Ciudad Victoria, Tamaulipas, México, 2002.

[24] A. W. Harvey, "Schistocera piceifrons (Walker) ( Orthoptera: Acrididae), the swarming locust of tropical America: a review," Bulletin of Entomological Research, vol. 73, no. 2, pp. 171-184, 1983.

[25] P. Hunter-Jones, "Life history of the Central American Locust, Schistocerca sp. (Orthoptera: Acrididae), in the laboratory," Annals of the Entomological Society of America, vol. 60, no. 2, pp. 468-477, 1967.

[26] N. D. Jago, A. Antonious, and J. P. Grunshaw, "Further laboratory evidence for the separate species status of the South American locust (Schistocerca cancellata Serville) and the Central American locust (Schistocerca piceifrons piceifrons Walker) (Acrididae, Cyrtacanthacridinae)," Journal of Natural History, vol. 16, pp. 763-768, 1982.

[27] Z. Waloff and D. E. Pedgley, "Comparative biogeography and biology of the South American locust, Schistocerca cancellata (Serville), and the South African desert locust, S. gregaria flaviventris (Burmeister) (Orthoptera: Acrididae): a review," Bulletin of Entomological Research, vol. 76, pp. 1-20, 1986.

[28] C. Bruch, "Investigaciones sobre la langosta, experimentos en cautividad," Memoria de la Comision Central de Investigaciones sobre la Langosta, vol. 1936, pp. 143-190, 1939.

[29] J.-F. Duranton, A. Monard, and R. S. Morales, "Contribution à l'étude de la bio-écologie de deux locustes péruviens, Schistocerca cf. interrita Scudder 1899 et Schistocerca piceifrons peruviana Lynch Arribalzaga 1903 (Orthoptera, Cyrtacanthacridinae)," Journal of Orthoptera Research, vol. 15, no. 2, pp. 157-169, 2006.

[30] J.-F. Duranton, A. Monard, and R. S. Morales, "Outbreaks of Schistocerca interrita (Scudder, 1899) in Northern Peru," in Proceedings of the 8th International Meeting of the Orthopterists' Society, vol. 8, p. 76, Montpellier, France, 2001. 
[31] R. S. Morales, “, Langosta plaga en el Perú (Schistocerca piceifrons peruviana; S. interrita). Manejo y control," in Manejo Integrado de la Langosta Centroamericana (Schistocerca piceifrons piceifrons, Walker) y Acridoideos Plaga en América Latina, L. Barrientos-Lozano and P. AlmaguerSierra, Eds., pp. 180-198, Instituto Tecnológico de Cd. Victoria, Cd. Victoria, Tamaulipas, México, 2005.

[32] SENASA, "Integrated management for acridids: locusts \& grasshoppers in Peru," 2010, http://www.senasa.gob.pe/ servicios/eng/agriculturist/im_acridids/index.htm.

[33] J. C. Faure, "The phases of locusts in South Africa," Bulletin of Entomological Research, vol. 23, pp. 293-405, 1932.

[34] A. Franc, L. Rabesisoa, M. H. Luong-Skovmand, and M. Lecoq, "Phase polymorphism in the red locust, Nomadacris septemfasciata (Orthoptera: Acrididae) in Madagascar," International Journal of Tropical Insect Science, vol. 25, no. 3, pp. 182-189, 2005.

[35] V. M. Dirsh, "A new biometrical phase character in locusts," Nature, vol. 167, no. 4242, pp. 281-282, 1951.

[36] A. Antoniou, "Observations on rearing and breeding the Bombay locust Patanga succincta (L.), in the laboratory," Journal of Natural History, vol. 4, pp. 85-88, 1970.

[37] S. Tanaka and T. Okuda, "Life cycles, diapause and developmental characteristics in subtropical locusts, Nomadacris succincta and N. japonica (Orthoptera: Acrididae)," Japanese Journal of Entomology, vol. 64, no. 1, pp. 189-201, 1996.

[38] R. J. Elder, "Bionomics of Austracris guttulosa (Walker) (Orthoptera: Acrididae) during the 1970-75 Outbreak in Queensland, Australia," Australian Journal of Entomology, vol. 36, no. 1, pp. 57-67, 1997.

[39] R. J. Elder, "Laboratory studies on the life history of Nomadacris guttulosa (Walker) (Orthoptera: Acrididae)," Journal of the Australian Entomological Society, vol. 28, pp. 247-253, 1989.

[40] R. J. Elder, "Morphometrics of field populations of Austracris guttulosa (Walker) (Orthoptera: Acrididae) in Australia," Australian Journal of Entomology, vol. 35, no. 4, pp. 345-347, 1996.

[41] G. B. Popov, Nymphs of the Sahelian Grasshoppers: An Illustrated Guide, Overseas Development Natural Resources Institute, Chatham, UK, 1989.

[42] G. Popov and M. Ratcliffe, "The Sahelian tree locust Anacridium melanorhodon (Walker)," Anti-Locust Memoir, vol. 9, pp. 1-48, 1968.

[43] D. J. Nolte, "The gregarization of locusts," Biological Reviews of the Cambridge Philosophical Society, vol. 49, pp. 1-14, 1974.

[44] F. B. Common, "The yellow-winged locust, Gastrimargus musicus Fabr., in central Queensland," Queensland Journal of Agricultural Science, vol. 5, pp. 153-219, 1948.

[45] G. Popov, "Apparent tendency to phase variation in an Iranian grasshopper, Pyrgodera armata (F. W.) (Orthoptera, Acrididae)," European Optical Society, vol. 28, pp. 277-283, 1952.

[46] K. H. L. Key, The Taxonomy, Phases and Distribution of the Genera Chortoicetes Brunn. and Austroicetes Uv. (Orthoptera: Acrididae), CSIRO Division of Entomology, Canberra, Australia, 1954.

[47] Y. Heifetz and S. W. Applebaum, "Density-dependent physiological phase in a non-migratory grasshopper Aiolopus thalassinus," Entomologia Experimentalis et Applicata, vol. 77, no. 3, pp. 251-262, 1995.

[48] A. V. Latchininsky, Acridids of Kazakhstan, Central Asia and Adjacent Territories, Association for Applied Acridology
International, University of Wyoming, Laramie, Wyo, USA, 2002.

[49] K. A. Vasil'ev, “The Italian locust Calliptamus italicus in central Kazakhstan,” Trudy Nauchno-Issledovatel'skogo Institute Zashchity Rastenil, Alma-Ata, vol. 7, pp. 123-190, 1962.

[50] K. A. Vasil'ev, "Phases in the Italian locust (Calliptamus italicus L.)," Doklady Akademii Nauk SSSR, vol. 74, pp. 639642, 1950.

[51] M. V. Stolyarov, "The Italian locust Calliptamus italicus L. (Orthoptera, Acrididae) in Kara-Kalpakia," Entomologicheskoe Obzrenie, vol. 46, pp. 615-628, 1967.

[52] A. V. Latchininsky and M. H. Launois-Luong, Le Criquet Marocain, Dociostaurus Maroccanus (Thunberg, 1815), dans la Partie Orientale de son Aire de Distribution, CRADPRIFAS, Montpellier, France, 1992.

[53] P. Barranco and F. Pascual, "Biometría, comportamiento y coloración de una población gregaria de langosta marroquí, Dociostaurus maroccanus (Thunberg, 1815), en las proximidades del Cabo de Gata (Almería, España)," Boletín de Sanidad Vegetal Plagas, vol. 21, pp. 203-211, 1995.

[54] I. Pierozzi Jr. and M. Lecoq, "Morphometric studies on Rhammatocerus schistocercoides (Rehn, 1906) [Orthoptera, Acrididae, Gomphocerinae] in Brazilian and Colombian populations," Transactions of the American Entomological Society, vol. 124, no. 1, pp. 25-34, 1998.

[55] E. E. Ebratt, C. Espinel, and A. M. Cotes, "Estudio de la teoría de fases en Rhammatocerus schistocercoides (Orthoptera: Acrididae) en los Llanos Orientales de Colombia," Revista Colombiana de Entomología, vol. 26, no. 3-4, pp. 83-88, 2000.

[56] A. V. Latchininsky, "Grasshopper problems in Yacutia (Eastern Siberia, Russia) Grasslands," Journal of Orthoptera Research, vol. 4, pp. 29-34, 1995.

[57] R. L. Shotwell, "A study of the lesser migratory grasshopper," UDSA Technical Bulletin 190, 1930.

[58] D. J. Fielding and L. S. Defoliart, "Density and temperaturedependent melanization of fifth-instar Melanoplus sanguinipes: interpopulation comparisons," Journal of Orthoptera Research, vol. 14, no. 1, pp. 107-113, 2005.

[59] J. R. Parker and R. L. Shotwell, "Devastation of a large area by the differential and the two-striped grasshoppers," Journal of Economic Entomology, vol. 25, pp. 174-196, 1932.

[60] R. E. Pfadt, Field Guide to Common Western Grasshoppers, vol. 912, Wyoming Agricultural Experiment Station Bulletin, 3rd edition, 2002.

[61] G. B. Popov, L. D. McComie, and M. H. Launois-Luong, "The Moruga grasshopper in Trinidad Coscineuta virens (Thunberg 1815) (Acrididae: Proctolabinae)," Journal of Orthoptera Research, vol. 2, pp. 49-60, 1994.

[62] L. C. Kuitert and R. V. Connin, "Biology of the American grasshopper in the southeastern United States," The Florida Entomologist, vol. 35, no. 1, pp. 22-33, 1952.

[63] G. A. Sword, "To be or not to be a locust? A comparative analysis of behavioral phase change in nymphs of Schistocerca americana and S. gregaria," Journal of Insect Physiology, vol. 49, no. 7, pp. 709-717, 2003.

[64] A. W. Harvey, "Hybridization studies in the Schistocerca americana complex. I. The specific status of the Central American Locust," Biological Journal of the Linnean Society, vol. 12, no. 4, pp. 349-355, 1979.

[65] A. Antoniou and C. J. Robinson, "Laboratory studies on the effect of crowding on phase and the life history of Schistocerca pallens (Thunberg) (Orthoptera: Acrididae: Cyrtacanthacridinae)," Journal of Natural History, vol. 8, pp. 701-715, 1974. 
[66] N. P. Duck, "The bionomics of Schistocerca obscura (Fabr)," Journal of the Kansas Entomological Society, vol. 17, no. 3, pp. 105-119, 1944.

[67] D. K. M. Kevan, "An account of Schistocerca flavofasciata (De Geer 1773) in Trinidad (Orthoptera: Acrididae)," Bulletin of Entomological Research, vol. 34, pp. 291-310, 1943.

[68] C. H. F. Rowell and T. L. Cannis, "Environmental factors affecting the green/brown polymorphism in the cyrtacanthacridine grasshopper Schistocerca vaga (Scudder)," Acrida, vol. 1, pp. 69-77, 1971.

[69] G. A. Sword, "Density-dependent warning coloration," Nature, vol. 397, no. 6716, p. 217, 1999.

[70] G. H. Schmidt and R. Albütz, "Identification of solitary and gregarious populations of the desert Locust, Schistocerca gregaria, by experimental breeding (Caelifera: Acrididae)," Entomologia Generalis, vol. 24, no. 3, pp. 161-175, 1999.

[71] G. A. Sword, "A role for phenotypic plasticity in the evolution of aposematism," Proceedings of the Royal Society B: Biological Sciences, vol. 269, no. 1501, pp. 1639-1644, 2002.

[72] A. Yassin, C. Amédégnato, C. Cruaud, and M. Veuille, "Molecular taxonomy and species delimitation in Andean Schistocerca (Orthoptera: Acrididae)," Molecular Phylogenetics and Evolution, vol. 53, no. 2, pp. 404-411, 2009.

[73] V. M. Hernández-Vélazquez, A. M. Berlanga-Padilla, and E. Garza-González, "Detección de Metarhizium flavoviride sobre Schistocerca piceifrons piceifrons (Orthoptera:Acrididae) en la Isla Socorro, Archipielago de Revillagigedo, México," Vedalia, vol. 4, pp. 45-46, 1997.

[74] H. Song, D. B. Weissman, L. Barrientos-Lozano, and Z. Cano-Santana, "The Locust island," American Entomologist, vol. 52, no. 3, pp. 168-181, 2006.

[75] P. Köhler, "Ecología de la zona central y de gregarisación de la langosta en la Republica Argentina," Idia Supplement, vol. 7, pp. 1-108, 1962.

[76] D. M. Hunter and E. L. Cosenzo, "The origin of plagues and recent outbreaks of the South American locust, Schistocerca cancellata (Orthoptera: Acrididae) in Argentina," Bulletin of Entomological Research, vol. 80, no. 3, pp. 295-300, 1990.

[77] S. H. Scudder, "The Orthopteran genus Schistocerca," Proceedings of the American Academy of Arts and Sciences, vol. 34, pp. 439-476, 1899.

[78] B. P. Uvarov, "A revision of the Old World Cyrtacanthacrini (Orthoptera, Acrididae) I. Introduction and key to genera," The Annals and Magazine of Natural History, vol. 9, no. 11, pp. 130-145, 1923.

[79] V. M. Dirsh, "Patanga Uvarov, 1923 (Insecta, Orthoptera): proposed designation of a type-species under the plenary powers Z.N.(S.) 1761," Bulletin of Zoological Nomenclature, vol. 23, no. 5, pp. 235-238, 1966.

[80] B. P. Uvarov, "Comments on application by V.M. Dirsh regarding the type species of Patanga Uvarov. Z.N.(S.) 1761," Bulletin of Zoological Nomenclature, vol. 24, pp. 132-135, 1967.

[81] R. V. Melville, "Review of the case concerning the generic names Patanga Uvarov, 1923, and Valanga Uvarov, 1923 (Insecta, Orthoptera) Z.N.(S.) 1761," Bulletin of Zoological Nomenclature, vol. 26, no. 2, pp. 78-83, 1969.

[82] R. V. Melville, "Opinion 998. Gryllus Locusta succinctus Linnaeus, 1763 (Insecta, Orthoptera: neotype designated under the plenary powers," Bulletin of Zoological Nomenclature, vol. 30, pp. 77-79, 1973.

[83] V. M. Dirsh, "The species and synonymy of the genus Cyrtacanthacris (Orth., Acrididae)," European Optical Society, vol. 53, pp. 35-50, 1979.
[84] N. D. Jago, "The genus Nomadacris Uvarov, 1923 and its recent incorrect synonymy under Cyrtacanthacris Walker, 1870 (Acrididae, Cyrtacanthacridinae), with new nomenclatural changes in the Patanga-Nomadacris-Austracris Complex," Plant Protection Bulletin, vol. 33, no. 3-4, pp. 39-43, 19891.

[85] K. H. L. Key and N. D. Jago, "Nomadacris Uvarov, 1923 (Insecta, Orthoptera): proposed conservation by setting aside the first-reviser action of Jago, 1981. Z.N.(S.)2525," Bulletin of Zoological Nomenclature, vol. 43, no. 1, pp. 102-104, 1986.

[86] K. H. L. Key and D. C. F. Rentz, "On the scientific name of the Australian "Spur-throated locust" (Orthoptera: Acrididae)," Journal of the Australian Entomological Society, vol. 33, pp. 345-346, 1994.

[87] G. F. Burnett, "Observations on the life-history of the red locust, Nomadacris septemfasciata (Serv.) in the solitary phase," Bulletin of Entomological Research, vol. 42, pp. 473490, 1951.

[88] G. F. Burnett, "Field observations on the behaviour of the red locust (Nomadacris septemfasciata Serville) in the solitary phase," Anti-Locust Bulletin, vol. 8, pp. 1-36, 1951.

[89] R. F. Chapman, "Field observations on the behaviour of hoppers of the red locust (Nomadacris septemfasciata Serville)," Anti-Locust Bulletin, vol. 33, pp. 1-51, 1959.

[90] G. J. W. Dean, "Observations on the structure of hopper bands and movement of hoppers of the red locust (Nomadacris septemfasciata Serville)," Journal of the Entomological Society of Southern Africa, vol. 30, no. 1, pp. 1-17, 1967.

[91] G. J. W. Dean, "Studies of factors affecting the formation of hopper bands of the red locust (Nomadacris septemfasciata) in an outbreak area," The Journal of Applied Ecology, vol. 5, no. 2, pp. 273-290, 1968.

[92] A. Franc and M. H. Luong-Skovmand, "Life cycle, reproductive maturation, and wing color changes in Nomadacris septemfasciata (Orthoptera: Acrididae) in Madagascar," Environmental Entomology, vol. 38, no. 3, pp. 569-576, 2009.

[93] J. Roffey, "Locusts and grasshoppers of economic importance in Thailan," Anti-Locust Memoir, vol. 14, pp. 1-200, 1979.

[94] D. R. Bhatia and M. V. Venkatesh, "Some observations on the Bombay locust, Patanga succincta (Linn.) in India," Indian Journal of Entomology, vol. 31, no. 4, pp. 297-310, 1969.

[95] R. J. Douthwaite, "Behaviour of nymphs of the Bombay locust, Patanga succincta (L.), in Thailand," Acrida, vol. 5, pp. 261-266, 1976.

[96] G. L. Baker, Locusts and Grasshoppers of the Australian Region, The Orthopterists' Society, Quebec, Canada, 1993.

[97] D. M. Hunter, P. W. Walker, and R. J. Elder, "Adaptations of locusts and grasshoppers to the low and variable rainfall of Australia," Journal of Orthoptera Research, vol. 10, no. 2, pp. 347-351, 2001.

[98] V. M. Dirsh and B. P. Uvarov, "Tree locusts of the genus Anacridium (Orthoptera, Acrididae)," European Optical Society, vol. 29, pp. 7-69, 1953.

[99] M. Fries, W. Chapco, and D. Contreras, "A molecular phylogenetic analysis of the Oedipodinae and their intercontinental relationships," Journal of Orthoptera Research, vol. 16, no. 2, pp. 115-125, 2007.

[100] M. C. Todd, R. Washington, R. A. Cheke, and D. Kniveton, "Brown locust outbreaks and climate variability in southern Africa," Journal of Applied Ecology, vol. 39, no. 1, pp. 31-42, 2002.

[101] B. P. Uvarov, "A revision of the genus Locusta, L. (= Pachytylus, Fieb.), with a new theory as to the periodicity and 
migrations of locusts," Bulletin of Entomological Research, vol. 12, pp. 135-163, 1921.

[102] J. M. Ritchie, "A taxonomic revision of the genus Oedaleus Fieber (Orthoptera: Acrididae)," Bulletin of the British Museum (Natural History) Entomology, vol. 42, no. 3, pp. 83$183,1981$.

[103] I. H. Maiga, M. Lecoq, and C. Kooyman, "Ecology and management of the Senegalese grasshopper Oedaleus senegalensis (Krauss 1877) (Orthoptera: Acrididae) in West Africa: review and prospects," Annales de la Société Entomologique de France, vol. 44, no. 3, pp. 271-288, 2008.

[104] A. Batten, "The Senegalese grasshopper Oedaleus senegalensis Krauss," Journal of Applied Ecology, vol. 6, pp. 27-45, 1969.

[105] J. M. Ritchie, "Melanism in Oedaleus senegalensis and other oedipodines (Orthoptera, Acrididae)," Journal of Natural History, vol. 12, pp. 153-162, 1978.

[106] M. Launois and M. H. Launois-Luong, The Senegalese Grasshopper, Oedaleus Senegalensis (Krauss 1877), in West Africa, The Orthopterists' Society, Quebec, Canada, 1991.

[107] L. Kang, X. Han, Z. Zhang, and O. J. Sun, "Grassland ecosystems in China: review of current knowledge and research advancement," Philosophical Transactions of the Royal Society B: Biological Sciences, vol. 362, no. 1482, pp. 997-1008, 2007.

[108] A. J. Cease, S. Hao, L. Kang, J. J. Elser, and J. F. Harrison, "Are color or high rearing density related to migratory polyphenism in the band-winged grasshopper, Oedaleus asiaticus?" Journal of Insect Physiology, vol. 56, pp. 926-936, 2010.

[109] J. M. Ritchie, "A taxonomic revision of the genus Gastrimargus Saussure (Orthoptera: Acrididae)," Bulletin of the British Museum (Natural History) Entomology, vol. 44, no. 4, pp. 239-329, 1982.

[110] A. P. L. Commission, “Australian Plague Locust," 2010, http://www.daff.gov.au/animal-plant-health/locusts/about/ australia.

[111] C. Willemse, "On a collection of Orthoptera from the Sumba Islands (Indonesia). Wissenschaftliche Ergebnisse der Sumba-Expedition des Museums für Völkerkunde unde des Naturhistorischen Museums in Basel, 1949," Verhandlungen der Naturforschenden Gesellschaft in Basel, vol. 64, no. 1, pp. 89-104, 1953.

[112] D. Hollis, "New combinations affecting the genus Aiolopus (Orthoptera: Acridoidea) and a description of a related new genus and species from Australia," Journal of Natural History, vol. 1, pp. 157-162, 1967.

[113] D. A. Cullen, G. A. Sword, T. Dodgson, and S. J. Simpson, "Behavioural phase change in the Australian plague locust, Chortoicetes terminifera, is triggered by tactile stimulation of the antennae," Journal of Insect Physiology, vol. 56, pp. 937$942,2010$.

[114] D. Hollis, "A revision of the genus Aiolopus Fieber (Orthoptera: Acridoidea)," Bulletin of the British Museum (Natural History) Entomology, vol. 22, no. 7, pp. 309-355, 1968.

[115] R. J. V. Joyce, "The ecology of grasshoppers in east central Sudan," Anti-Locust Bulletin, vol. 11, pp. 1-99, 1952.

[116] M. G. Sergeev and I. A. Van'kova, "Dynamics of the Italian locust Calliptamus italicus L. population in the southwest of the west Siberian plain," Contemporary Problems of Ecology, vol. 1, no. 2, pp. 204-209, 2008.
[117] A. V. Latchininsky, "Moroccan locust Dociostaurus maroccanus (Thunberg, 1815): a faunistic rarity or an important economic pest?" Journal of Insect Conservation, vol. 2, no. 34, pp. 167-178, 1998.

[118] E. Quesada-Moraga and C. Santiago-Álvarez, "Rearing and breeding of the Moroccan locust Dociostaurus maroccanus (Thunberg) (Orthop., Acrididae) under laboratory conditions," Journal of Applied Entomology, vol. 125, no. 3, pp. 121124, 2001.

[119] L. F. H. Merton, "Studies in the ecology of the Moroccan locust (Dociostaurus maroccanus Thunberg) in Cyprus," Anti-Locust Bulletin, vol. 34, pp. 1-123, 1959.

[120] M. Lecoq, A. Foucart, and G. Balança, "Behaviour of Rhammatocerus schistocercoides (Rehn, 1906) hopper bands in Mato Grosso, Brazil (Orthoptera : Acrididae : Gomphocerinae)," Annales de la Societe Entomologique de France, vol. 35, no. 2, pp. 217-228, 1999.

[121] M. Lecoq and I. Pierozzi Jr., "Flight behaviour of Rhammatocerus schistocercoides (Rehn, 1906) swarms in the state of Mato Grosso in Brazil (Orthoptera : Acrididae, Gomphocerinae)," Annales de la Société Entomologique de France, vol. 32, no. 3, pp. 265-283, 1996.

[122] M. Lecoq and I. Pierozzi Jr., "Chromatic polymorphism and geophagy: two outstanding characteristics of Rhammatocerus schistocercoides (Rehn 1906) grasshoppers in Brazil [Orthoptera, Acrididae, Gomphocerinae]," Journal of Orthoptera Research, vol. 5, pp. 13-17, 1996.

[123] J. A. Lockwood, Locust: The Devastating Rise and Mysterious Disappearance of the Insect that Shaped the American Frontier, Basic Books, New York, NY, USA, 2004.

[124] J. C. Faure, "The phases of the Rocky Mountain locust Melanoplus mexicanus (Saussure)," Journal of Economic Entomology, vol. 26, pp. 706-718, 1933.

[125] U. S. G. Survey, "First Annual Report of the United States Entomological Commission for the year 1877 relating to the Rocky Mountain Locust and the best methods of preventing its injuries and of guarding against its invasions, in pursuance of an appropriation made by congress for this purpose," Government Printing Office, Wahsington, 1878.

[126] J. R. Parker, R. C. Newton, and R. L. Shotwell, "Observations on mass flights and other activities of the migratory grasshopper," UDSA Technical Bulletin 1109, 1995, pp.1-46.

[127] D. C. Eades, D. Otte, M. M. Cigliano, and H. Braun, "Orthoptera Species File Online," Version 2.0/4.0, 2010, http://Orthoptera.SpeciesFile.org.

[128] G. Huo, G. Jiang, Z. Sun, D. Liu, Y. Zhang, and L. $\mathrm{Lu}$, "Phylogenetic reconstruction of the family Acrypteridae (Orthoptera: Acridoidea) based on mitochondrial cytochrome B gene," Journal of Genetics and Genomics, vol. 34, no. 4, pp. 294-306, 2007.

[129] H. Wang and R. V. Varma, Insect Pests of Bamboos in Asia-An Illustrated Manual, International Network for Bamboo and Rattan, 1998.

[130] H.-Y. Mao, "Relation between the occurence and environmental factors of the yellow-spined bamboo locust," Acta Phytophylacica Sinica, vol. 2, no. 1, pp. 88-94, 1963.

[131] N. P. Peng, "Biological notes on the bamboo-locust (Ceracris kiangsu Tsai) of Hunan, China," Acta Entomologica Sinica, vol. 188, pp. 188-200, 1958.

[132] K. Shen, H.-J. Wang, L. Shao et al., "Mud-puddling in the yellow-spined bamboo locust, Ceracris kiangsu (Oedipodidae: Orthoptera): does it detect and prefer salts or nitrogenous compounds from human urine?" Journal of Insect Physiology, vol. 55, no. 1, pp. 78-84, 2009. 
[133] C.-H. Zhu, Z.-J. Zhu, and Z.-D. Wu, "Experiment of Ceracris kiansu control with medicated urine," Journal of Zhejiang Foresty Science and Technology, vol. 25, no. 5, pp. 32-33, 2005.

[134] C. H. F. Rowell and P. K. Flook, "A dated molecular phylogeny of the Proctolabinae (Orthoptera, Acrididae), especially the Lithoscirtae, and the evolution of their adaptive traits and present biogeography," Journal of Orthoptera Research, vol. 13, no. 1, pp. 35-56, 2004.

[135] K. H. L. Key, "A critique on the phase theory of locusts," The Quarterly Review of Biology, vol. 25, no. 4, pp. 363-407, 1950.

[136] D. R. Brooks and D. A. McLennan, Phylogeny, Ecology, and Behavior: A Research Program in Comparative Biology, The University of Chicago Press, Chicago, Ill, USA, 1991.

[137] S. J. Simpson, E. Despland, B. F. Hägele, and T. Dodgson, "Gregarious behavior in desert locusts is evoked by touching their back legs," Proceedings of the National Academy of Sciences of the United States of America, vol. 98, no. 7, pp. 3895-3897, 2001.

[138] D. Bensasson, D.-X. Zhang, and G. M. Hewitt, "Frequent assimilation of mitochondrial DNA by grasshopper nuclear genomes," Molecular Biology and Evolution, vol. 17, no. 3, pp. 406-415, 2000.

[139] H. Song, J. E. Buhay, M. F. Whiting, and K. A. Crandall, "Many species in one: DNA barcoding overestimates the number of species when nuclear mitochondrial pseudogenes are coamplified," Proceedings of the National Academy of Sciences of the United States of America, vol. 105, no. 36, pp. 13486-13491, 2008.

[140] G. A. Sword, L. B. Senior, J. F. Gaskin, and A. Joern, "Double trouble for grasshopper molecular systematics: intraindividual heterogeneity of both mitochondrial $12 \mathrm{~S}$-valine$16 \mathrm{~S}$ and nuclear internal transcribed spacer ribosomal DNA sequences in Hesperotettix viridis (Orthoptera: Acrididae)," Systematic Entomology, vol. 32, no. 3, pp. 420-428, 2007. 

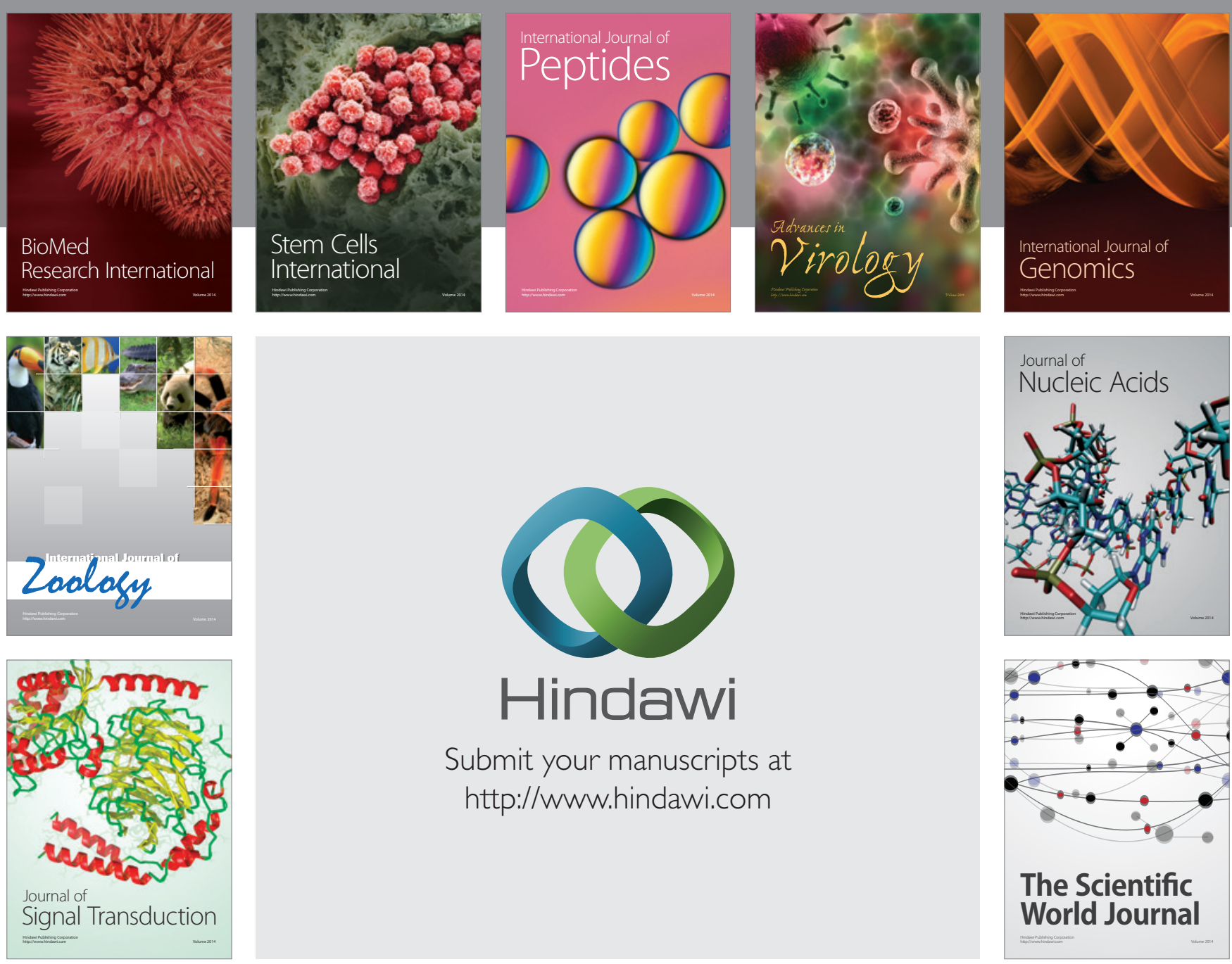

Submit your manuscripts at

http://www.hindawi.com
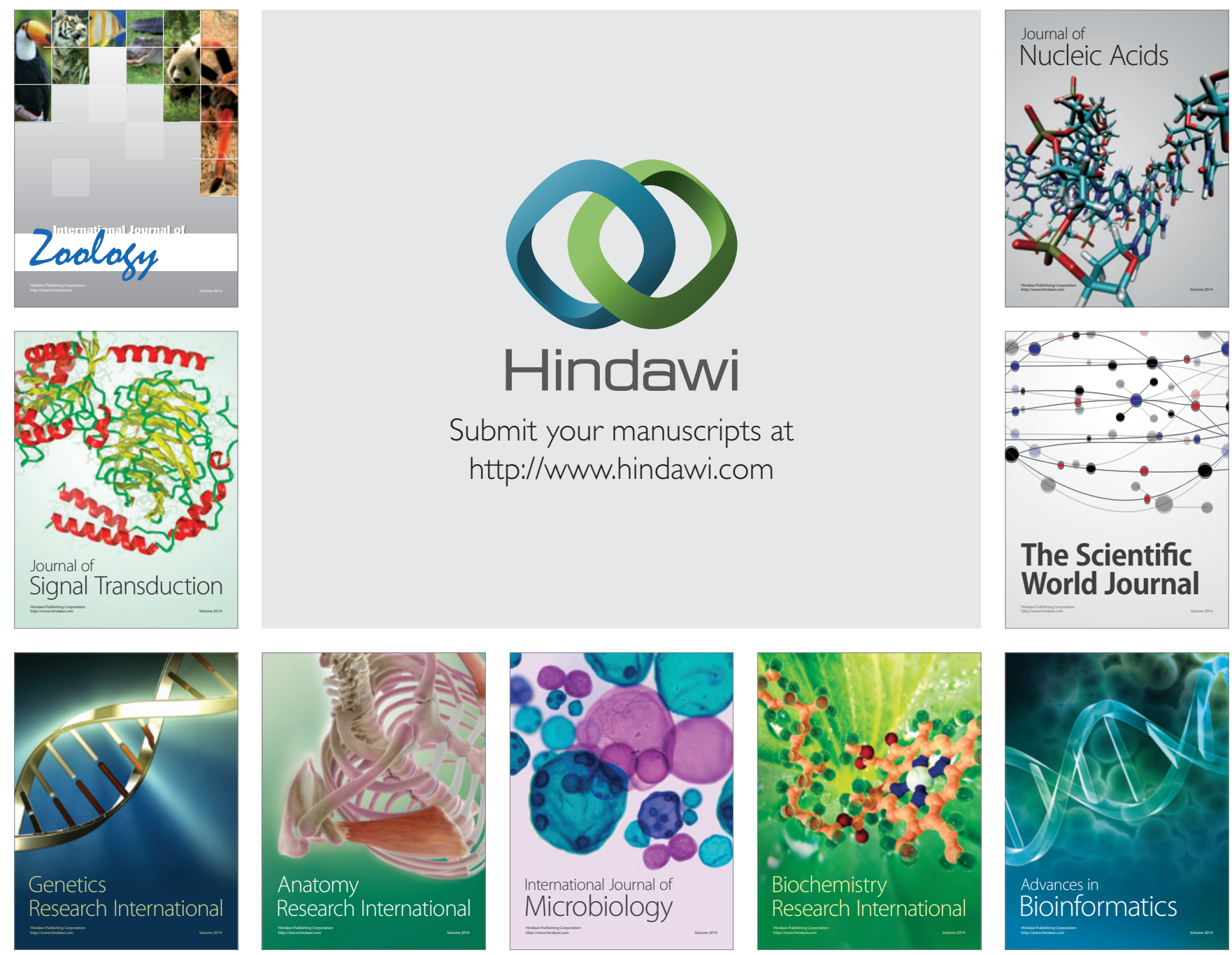

The Scientific World Journal
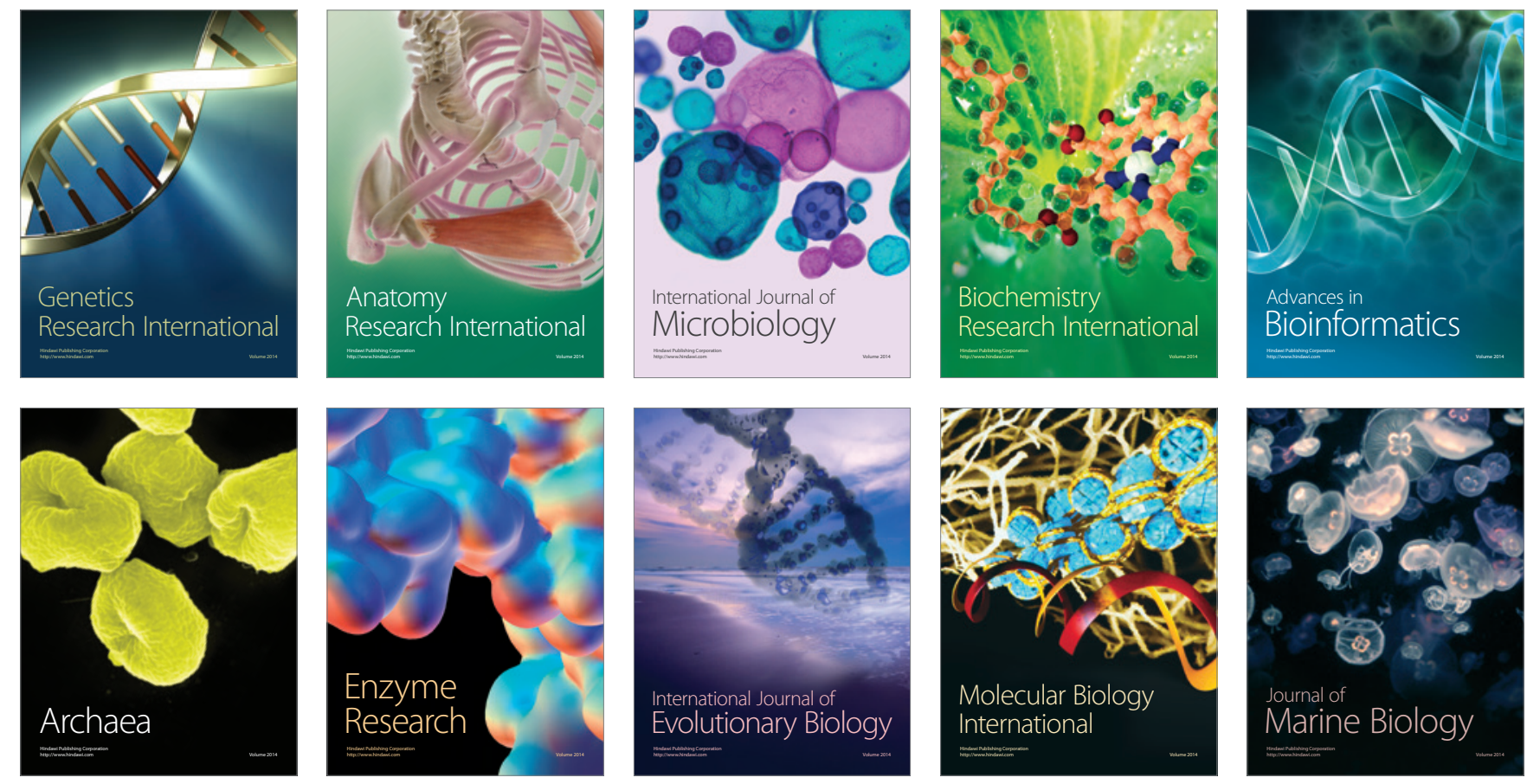